\title{
Framework Legislation for Commercial Activities in the Area
}

\author{
Erik Røsceg
}

When commercial activities, primarily mining, ${ }^{1}$ are carried out in the Area, ${ }^{2}$ a framework of commercial law is as helpful on sea as on land. For example, workers should be protected against unfair contract terms, and entrepreneurs should be able to mortgage their equipment to ease financing. However, there is no state to provide this legal framework by general legislation. Could it be established in other ways?

The International Seabed Authority (ISA) ${ }^{3}$ has a mandate to grant licenses for the exploitation of seabed resources in the Area, including setting conditions to ensure, for example, environmental protection and safety. ${ }^{4}$ This could work well to establish some of the desired legal framework, at least to the extent that states are parties to UNCLOs or recognize the Authority. ${ }^{5}$

The ISA possesses considerable power in granting licenses with conditions and revoking them if necessary. ${ }^{6}$ In addition, the risk of not getting licenses in the future can have a disciplinary effect.

However, not all kinds of rules can be implemented in this way. ${ }^{7}$ For example, conditions for licenses cannot be used to alter the position of third parties to their detriment. An example of framework legislation that cannot be simulated by setting conditions for licenses is arrangements for mortgaging seabed installations.

1 Which activities follows the rules in respect of mining and which other activities there are in the Area are elaborated in section 4 below.

2 The Area is defined in UNCLOS art. 1(1)(1).

3 This is the "Authority" referred to in UNCLOS; see art. 1(1)(2).

4 See below in part 2.1.

5 Notably, the USA is not a party to UNCLOS. However, US firms apparently register subsidiaries in States Parties if they wish to participate in industrial exploitation in the Area.

6 See below in part 2.1.

7 Ibid. 
Because of these limitations, there may be a need for regulation that is more comprehensive than what can be achieved by adding conditions to licenses. This paper focuses on rules of this kind. How is the possible need for such legislation taken care of in the Area? How can the necessary commercial framework legislation be implemented?

In the following, the main general jurisdictional bases will be discussed in section 2. These are the powers of ISA under UNCLOS, flag state jurisdiction and the jurisdiction of the sponsoring states and other states over companies. In section 3, some examples of how the jurisdictional problems are resolved or not resolved will be discussed. These examples concern patents, security interests (such as mortgages), labor law, and extra contractual liabilities.

Initially, the discussion will assume that the commercial activity is within the authority of the ISA. In section 4 below, the situation outside the authority of the ISA will be discussed.

\section{General Jurisdictional Bases}

\subsection{Incidental Jurisdiction of the ISA in Respect of Commercial Framework Legislation}

While coastal states have "sovereign rights" for the purpose of, for example, continental shelf jurisdiction, ${ }^{8}$ the International Seabed Authority has more limited powers. In respect of licensing, a number of policies are set out in UNCLOS, ${ }^{9}$ and there is a list of conditions (albeit non-exhaustive) in its Annex..$^{10}$

Although the ISA has mainly focused on granting and setting conditions for licenses, its mandate is broader, and can possibly be utilized to create the necessary commercial framework legislation. The mandate for the ISA reads:

$8 \quad$ UNCLOS art. 77.

9 UNCLOS art. $150 \mathrm{ff}$.

10 UNCLOS, Annex III, in particular art. 17. The conditions are set out in the so-called Mining Code, consisting of a number of regulations. To date, the Authority has issued Regulations on Prospecting and Exploration for Polymetallic Nodules in the Area (ISBA 19/C/17, adopted 13 July 2000) which was later updated and adopted 25 July 2013 (ISBA 19/A/9); the Regulations on Prospecting and Exploration for Polymetallic Sulphides in the Area (ISBA /16/A/12 Rev.1, adopted 7 May 2010) and the Regulations on Prospecting and Exploration for Cobalt-Rich Crusts (ISBA 18/A/11, adopted 27 July 2012). The work is ongoing and, in the following, draft revisions and consolidations will also be referred to. 


\section{Article 157 Nature and fundamental principles of the Authority}

1. The Authority is the organization through which States Parties shall, in accordance with this Part, organize and control activities in the Area, particularly with a view to administering the resources of the Area.

2. The powers and functions of the Authority shall be those expressly conferred upon it by this Convention. The Authority shall have such incidental powers, consistent with this Convention, as are implicit in and necessary for the exercise of those powers and functions with respect to activities in the Area.

The first part of paragraph 2 apparently excludes implied powers, ${ }^{11}$ while the second sentence extends the powers to "incidental powers." This apparent contradiction reflects the power struggle in the negotiations, where the industrialized nations opposed granting wide, implied powers to the ISA. ${ }^{12}$ The text was repeated without clarification in the 1994 implementing agreement. ${ }^{13}$

It is difficult to reconcile the text with an absolute ban on necessary, incidental powers relating to organizing and controlling activities in the Area. Such incidental powers could be used to adopt commercial framework legislation if absolutely necessary.

11 Without such exclusion, additional powers would be implied. See for example ICJ, Certain Expenses of the United Nations (Article 17, paragraph 2, of the Charter), Advisory Opinion of 20 July 1962, ICJ Reports (1962), 151, 168.

12 V Scatz, art. 157, mn. 7 in Preulss, UNCLOS, 1st ed 2017, ED Brown, Sea-bed energy and minerals: the international legal regime, Vol. 2: Sea-bed mining (2001) p. 193, S Mahmoudi, The law of deep sea-bed mining: a study of the progressive development of international law concerning the management of the polymetallic nodules of the deep sea-bed (1987) p. 281, SN Nandan et al., United Nations Convention on the Law of the Sea, 1982 : a commentary : Vol. 6 : Articles 133 to 191, Annexes III and IV, Final act, Annex I, Resolution II, Agreement relating to the implementation of part XI, Documentary annexes (2002), art. 157 para 157.13 (b), FH Paolillo, The institutional arrangements for the international seabed and their impact on the evolution of international organizations, Collected Courses of the Hague Academy of International Law, Volume: 188 (1984), p. 273, BH Oxman, The Third United Nations Conference on the Law of the Sea: The Eighth Session (1979), 74 The American Journal of International Law 1 (1980), 15.

13 Agreement relating to the implementation of Part XI of the United Nations Convention on the Law of the Sea of 10 December 1982, Annex to UN Document A/RES/48/263, Annex, s. 1 (1). 
Such broad interpretation would be in line with ITLOs'14 findings that similar powers of a coastal state to regulate fisheries within its EEZ include regulations for offshore bunkering: $:^{15}$

217. The Tribunal is of the view that the regulation by a coastal State of bunkering of foreign vessels fishing in its exclusive economic zone is among those measures which the coastal State may take in its exclusive economic zone to conserve and manage its living resources under article 56 of the Convention read together with 64 article 62, paragraph 4, of the Convention. This view is also confirmed by State practice which has developed after the adoption of the Convention.

It is not obvious that this case is pertinent. Article 157 relating to the powers of the ISA does not refer to "sovereign rights" as does Article 56 relating to the EEZ. Furthermore, there is as yet no practice - and indeed no state practice one way or the other relating to the Area. Still, it is likely that a similar broad reading of the powers of the ISA would be permitted, as there is a practical need for it. In particular, this is so when there is no question of creeping jurisdiction on the part of the ISA at the expense of states.

However, if there is a work-around for the problem of lack of commercial framework legislation, it would not be necessary for the ISA to act, and there would be no incidental powers. In the text below, several such workarounds will be discussed.

If the IsA has competence to legislate, final court decisions on the legislation are enforceable in all States Parties to UNCLOS. ${ }^{16}$ The ISA may also withdraw licenses ${ }^{17}$ and take past performance into consideration when granting new licenses. ${ }^{18}$

The ISA has not yet issued legislation of this kind. There is a reason for this reluctance. Both the secretariat and the decision-making bodies have limited resources, and they are not able to deal with the intricacies of private and procedural law. In addition, the ISA is handicapped because there is no existing

14 The Seabed Dispute Chamber International Tribunal for the Law of the Sea (ITLOS) settles disputes between a state party and the ISA regarding the competence of ISA, UNCLOS art. 187 .

15 It Los Case No. 19 The M/V “Virginia G” Case (Panama/Guinea-Bissau).

16 UNCLOS, Annex III, art. 21(2).

17 UNCLOS, Annex III, art. 18.

18 UNCLOS, Annex III, art. 10. This article was modified by the 1994 implementing agreement (fn. 13), Annex, s. 1(13). 
regime to build on, and each participating state would be likely to insist that its traditions be preserved. Whether or not the ISA has the legal competence to deal with the matters discussed here is thus probably a moot point, as it may not be able to enact change in any event.

\subsection{Flag State Jurisdiction over Ships Involved in Seabed Activities}

The water column above the Area is part of the high seas. ${ }^{19}$ In the high seas, the flag state jurisdiction prevails. ${ }^{20}$ Flag states therefore have general jurisdiction over ships involved in seabed activities in the Area. There is no indication that the powers of the ISA are exclusive in all matters, so flag state jurisdiction could be a good alternative to the ISA's jurisdiction in private law and other matters not relating to licensing.

In respect of protection of human life, UNCLOS presupposes that the jurisdiction of the ISA should be ancillary to other international provisions, which typically are based on flag state jurisdiction in respect of ships:

\section{Article 146 Protection of human life}

With respect to activities in the Area, necessary measures shall be taken to ensure effective protection of human life. To this end the Authority shall adopt appropriate rules, regulations and procedures to supplement existing international law as embodied in relevant treaties.

Similarly, flag state jurisdiction supplements the ISA's jurisdiction in respect of pollution:

Article 209 Pollution from activities in the Area

1. International rules, regulations and procedures shall be established in accordance with Part XI to prevent, reduce and control pollution of the marine environment from activities in the Area. Such rules, regulations and procedures shall be re-examined from time to time as necessary.

2. Subject to the relevant provisions of this section, States shall adopt laws and regulations to prevent, reduce and control pollution of the marine environment from activities in the Area undertaken by vessels, installations, structures and other devices flying their flag or of their registry or operating under their authority, as the case may be. The requirements of

\footnotetext{
19 UNCLOS art. 86.

$20 \quad$ UNCLOS art. 87 and 92.
} 
such laws and regulations shall be no less effective than the international rules, regulations and procedures referred to in paragraph 1 .

The coastal states have no special part in the enforcement of such provisions, while flag state enforcement presumably is retained:

Article 215 Enforcement with respect to pollution from activities in the Area

Enforcement of international rules, regulations and procedures established in accordance with Part XI to prevent, reduce and control pollution of the marine environment from activities in the Area shall be governed by that Part.

Under flag state jurisdiction, flag states implement a number of conventionbased provisions that are impactful in private law matters. In addition to conventions like SOLAS ${ }^{21}$ and MARPOL, ${ }^{22}$ most flag states are parties to a number of conventions that are concerned with matters other than safety and pollution, such as arresting vessels, ${ }^{23}$ labor law, ${ }^{24}$ liens and mortgages, ${ }^{25}$ and anti-terrorism measures. ${ }^{26}$ Also, UNCLOS sets out the responsibility of flag states regarding their vessels. ${ }^{27}$ Through these provisions, flag state jurisdiction fills a considerable gap in the legislation concerning activities in the Area.

Not all flag states are party to all conventions, and ship owners are free to choose almost any flag state for their vessels. However, the states with flags of convenience tend to ratify private law conventions, and ship owners do not avoid these flag states, as order and predictability is more important than deregulation in private law. Conventions are often compromises between interested parties and are thus acceptable.

The conventions are not complete codes, despite their broad scope. Therefore, they have to be supplemented by national legislation. Such legislation may vary quite a bit. It could wind up not regulating offshore activities by

21 International Convention for the Safety of Life at Sea (sOLAS), 1974, as amended.

22 International Convention for the Prevention of Pollution from Ships, 1973, as modified by the Protocol of 1978 relating thereto and by the Protocol of 1997 (MARPOL).

23 International Convention Relating to the Arrest of Sea-Going Ships, 1952.

24 Maritime Labour Convention, 2006.

25 International Convention on Maritime Liens and Mortgages, 1993.

26 Convention for the Suppression of Unlawful Acts against the Safety of Maritime Navigation (SUA), 1988, as amended.

27 UNCLOS art. 94. 
will, by drafting errors, or simply because no one has considered the need for regulating industrial activity on the high seas, as opposed to ships simply sailing there. Therefore, flag state jurisdiction that is based only on international conventions may leave gaps in the regulation of the activities of ships operating in the Area.

Flag state regulation of ships is common and usually recognized in other states. Even if the legislation may not be given preference under choice of law rules, flag state legislation would prevent a legal vacuum. The ultimate sanction of the flag state against a ship disrespecting its legislation is to withdraw the right to fly its flag, leaving the ship subject to the jurisdiction of any state. In most cases, this would be regarded as a sanction too harsh.

Sometimes, a ship may be governed by the legislation of two cooperating states. The ownership of the vessel is registered in one state, while the vessel is flying the flag of another. ${ }^{28}$ For our purposes, this is irrelevant; the sum of the jurisdiction of the two states is neither greater nor smaller than the jurisdiction of a single flag state.

Different vessels involved in the same operation may fly different flags. Thus, different sets of rules may apply to each ship. However, experience from offshore exploitation indicates that this is not a practical problem. If there is a safety aspect to the differences in regulation, the ISA is certainly competent to issue supplementary rules. ${ }^{29}$

The main problem with flag state jurisdiction is that not all units in the Area are ships; for example, they may be platforms and excavators operating on the seabed. This is problematic in two regards.

First, the, the acquis of conventions relating to ships may not always apply. There is a need to fill this void with new rules and standards.

Second, the traditional role of the flag state to regulate may be challenged, and it may not even be clear which state is the flag state. A state may invoke personal jurisdiction over the owners, but that may be challenged, for example, by the operator's home state.

Both in respect of flag state jurisdiction of ships and similar jurisdiction of other units, UnClOS Annex III on Basic Conditions of Prospecting, Exploration and Exploitation restricts the use of flag state type of jurisdiction, etc.:

28 This is often referred to as bare boat registration or temporary change of flag.

29 See above in section 2.1. 
Article 21 Applicable law

3. No State Party may impose conditions on a contractor that are inconsistent with Part XI. However, the application by a State Party to contractors sponsored by it, or to ships flying its flag, of environmental or other laws and regulations more stringent than those in the rules, regulations and procedures of the Authority adopted pursuant to article 17, paragraph 2(f), of this Annex shall not be deemed inconsistent with Part XI.

This provision only applies in so far as the rules affect the licensee contractor negatively. Labor protection laws may be in this category, while the rule will most likely not affect legislation concerning legal infrastructure providing an option for mortgaging the unit used in the Area. If the licensee is affected, States Parties to UNCLOS cannot legislate, even if there is jurisdiction under the general principles of international law.

However, even when the licensee is affected negatively, flag state regulation of ships in respect of protection of the marine environment ${ }^{30}$ is expressly allowed, and so is similar regulation of sponsoring states. Sponsoring states are in a way the "flag state" of the licensee. ${ }^{31}$

The net result of article 21 in respect of commercial framework legislation is that there is a fairly wide discretion of flag states and the like to supplement the regulations of the ISA and UNCLOS if they have jurisdiction on other grounds.

Flag state jurisdiction appears to be dominating in respect of ships, also in the Area.

\subsection{Company Jurisdiction over Companies Involved in Seabed Activities}

In order to obtain a license, a private company must be sponsored by a state:

Article 153 System of exploration and exploitation

2. Activities in the Area shall be carried out as prescribed in paragraph 3:(b) in association with the Authority by States Parties, or state enterprises or natural or juridical persons which possess the nationality of States Parties or are effectively controlled by them or their nationals, when sponsored by such States, or any group of the foregoing which meets the requirements provided in this Part and in Annex III.

30 This follows from the reference to UNCLOS Annex III, art. 17(2)(f).

31 See below in section 2.3. 
The licensee must be effectively controlled by a sponsoring state. The sponsoring state (as all states parties) shall assist the ISA, ${ }^{32}$ and the sponsoring state has the responsibility to ensure that a licensee shall carry out activities in the Area in conformity with the terms. ${ }^{33}$ It is for that reason control is needed. If more than one state has control, they must all sponsor. ${ }^{34}$ The state in which a prospective licensee is registered (or in which the licensee is a national) must be a sponsoring state, but that does not always suffice. ${ }^{35}$ The involved states may be liable for failure to comply with this part of UNCLOS. ${ }^{36}$ The sponsoring state must issue a certificate of sponsorship. ${ }^{37}$

If a state can control a private entity to this extent, perhaps the same mechanism could be utilized to provide supplementary legislation to create commercial framework legislation, subject to the limitations discussed above. ${ }^{38}$ But how efficient is this kind of jurisdiction over a licensee or another company in the Area?

A problem could be that jurisdiction over the company is limited to the company. Thus, it is not able to address the relationships between different parties in the Area, such as the relationship between two subcontractors. Two examples of such relationships are provisions for knock-for-knock agreements ${ }^{39}$ and channeling of liability. ${ }^{40}$ Likewise, the state with jurisdiction over the company cannot regulate mortgages and other third-party relations when the third parties are the general creditors of the company. However, the sponsoring state can exercise its jurisdiction over the licensee or other companies under its control to ensure that it implements certain provisions in subcontracts.

Even when feasible as a regulatory technique, legislation of a sponsoring state may not be easily enforceable. If a company is registered in the

$32 \quad$ UCLOS art. 154(4).

33 UNCLOS, Annex III, art. 4(4).

34 UNCLOS, Annex III, art. 4(3).

35 Ibid.

36 UNCLOS art. 139, Responsibilities and obligations of States with respect to activities in the Area, Advisory Opinion, 1 February 2011, ITLOS Reports 2011, p. 10, and Kristoffer Svendsen's contribution to this volume.

37 Se for example Regulations on Prospecting and Exploration for Cobalt-Rich Crusts (fn. 10), reg. 11.

38 UNCLOS Annex III, art. 21; see above in section 2.2.

39 Knock-for-knock means that liability is waived in advance on a reciprocal basis in order to benefit from simpler and more inexpensive insurance arrangements made possible in this way.

40 Channeling of liability means that only one of several potential liability subjects shall be held liable in order to simplify claims handling. 
sponsoring state and that state has some jurisdiction thereby, the sponsoring state does not have full control. In particular, this is so if both the assets and the directors of the company are abroad and thus able to escape direct enforcement. If claims are enforced against the licensee to the extent that bankruptcy is declared, that may not take place in the land of registration and may not be subject to the laws of that state. ${ }^{41}$ However, winding-up as a sanction is a possibility, ${ }^{42}$ as well as withdrawal of the sponsorship of the licensee. ${ }^{43}$ These sanctions would in many cases be considered too strong.

In summary, the sponsoring state can contribute to commercial framework legislation in the Area. However, there are such limitations in both the scope and enforcement of such legislation that it is unlikely to be a feasible alternative.

\section{$3 \quad$ Examples}

\subsection{Introduction}

There is no doubt that commercial claims may be related to a site in the Area. In most cases, one can find ways to pursue the claims effectively, such as in the state where the damage occurred (in a torts claim) or in the home state of the debtor (in a contract claim). However, some problems are special to the Area in this respect.

First, there is the vacuum problem: Legislation that we take for granted on land or in coastal waters may not extend to the Area. Does a national rule of strict liability for pollution apply in the Area, or only in the territorial waters of the state in question? And do national rules on registration of mortgages in drilling rigs apply in the Area, or only on the continental shelf of the state

41 See, e.g., Regulation (EU) 2015/848 of the European Parliament and of the Council of 20 May 2015 on insolvency proceedings (recast), Art. 3, which locates insolvency proceedings to the center of main interest of the debtor (COMI), which may be a state other than the state of registration. This is also the rule in UnCitral Model Law on Cross-Border Insolvency with Guide to Enactment and Interpretation (2014), see para 31.

42 In Regulation (EU) 2015/848 (fn. 41), the compulsory winding-up of companies for reasons other than insolvency are not subject to the regulation, and then not necessarily its choice of forum to the COMI (Art. 1(1) of the Regulation).

43 ISA Document ISBA/24/LTC/WP.1/Rev.1, 9 July 2018, Draft Regulations on Exploitation of Mineral Resources in the Area, reg. 22. The sponsoring state may incur liability if it remains passive; see Kristoffer Svendsen's contribution to this volume. 
in question? If the rules do not apply, ${ }^{44}$ and the ISA has not issued such rules, there is a vacuum problem.

Such a vacuum may hamper commercial activities or leave vital interests without protection.

Second, there is the redundancy problem. It may happen that several states have made some of their legislation or other legal rules applicable worldwide or specifically in the Area. Which set of rules should prevail? This is traditionally governed by conflict of law rules, which vary between jurisdictions. The redundancy problem is likely to be an issue in the Area, as there is no natural presumption for which state's legislation shall apply; all situations will have only weak connections to states, and usually there are connections to many states.

Redundancy may cause a problem of forum shopping - legal action will be taken in the jurisdiction that will apply the rules that most benefit the party bringing the action. It is generally recognized that this is not a desirable system, both because it encourages parties to be the first to bring an action and because the foreseeability for the commercial parties is very limited.

In addition, some of the common choice of law rules are difficult to apply in the Area. One example is the general choice of law principle for property law, wherein the law of the state where the property is situated should be applied (lex rei sitae). This is relevant if, for example, there is an ownership dispute on machinery in the Area. Another example is the rule that the form of a document is governed by the law of the state in which the document is issued (locus regit actum, relevant if a bill of lading is issued at sea above the Area). New situations call for new private international legislation.

Some clauses in international investment treaties aim at protecting investors against less favorable framework legislation. Such treaties are unlikely to apply in the Area, to the national legislation applicable there and to the voting of states in the ISA. The ISA has not entered into any such agreements.

The following sections will discuss some situations in which the application of private law or private international law may cause problems in the Area in connection with different kinds of commercial framework legislation, namely patens, mortgages, labor law and liability.

44 Or the rules that one state has made applicable are not recognized by the court hearing the case. 


\subsection{Patents}

A patent is the exclusive right to manufacture, use, or sell an invention for a certain number of years. There are already a substantial number of patents related to deep seabed mining and other activities in the Area, and it is also likely that many general patents are used there. Is there, and could there be, a similar protection against patent infringements in the Area as on land?

There is no such thing as a patent that grants exclusive rights worldwide. Patent law is national, so each state has to issue a patent. A "world patent" is a collection of such national patents. However, to some extent the states do cooperate and recognize each other's patents.

In line with this recognition, states tend to limit the scope of patents (exclusive rights) issued by them to the territory including the territorial seas. ${ }^{45}$ Some states extend the scope of their patents to their own continental shelf. ${ }^{46}$ But to my knowledge, no state extends the patents beyond that, to the Area.

The ISA has not issued any rules on patents. Therefore, there is a vacuum problem here; there is no applicable patent law in the Area. This is unfortunate, as patents are likely to be just as beneficial for the commercial life in the Area as elsewhere.

The patented device may be on board or form a part of a ship or another unit operating in the Area. If the ship or unit enters a port, there is still no patent infringement as covered by a special rule in the Paris Convention: ${ }^{47}$

Article 5ter Patents: Patented Devices Forming Part of Vessels, Aircraft, or Land Vehicles

In any country of the Union the following shall not be considered as infringements of the rights of a patentee:

(i) the use on board vessels of other countries of the Union of devices forming the subject of his patent in the body of the vessel, in the machinery, tackle, gear and other accessories, when such vessels temporarily or accidentally enter the waters of the said country, provided that such devices are used there exclusively for the needs of the vessel;

(ii) the use of devices forming the subject of the patent in the construction or operation of aircraft or land vehicles of other countries of

\footnotetext{
45 A Stenvik, Patentrett (3rd ed. 2013) p. 282 ff and MCA Kant, Cross-Border Patent Infringement Litigation within the European Union (2015) p. $41 \mathrm{ff}$.

46 See, for example, Norwegian Petroleum Act, 1996, s. 1-5.

47 Paris Convention for the Protection of Industrial Property, 1883, as amended.
} 
the Union, or of accessories of such aircraft or land vehicles, when those aircraft or land vehicles temporarily or accidentally enter the said country.

These exceptions are wide, and make it difficult to enforce patents when used in the Area.

When this exception does not apply, a number of activities are defined as patent infringements. An example is the EU law:48

Article 25 Prohibition of direct use of the invention

A Community patent shall confer on its proprietor the right to prevent all third parties not having his consent:

(a) from making, offering, putting on the market or using a product which is the subject-matter of the patent, or importing or stocking the product for these purposes;

(b) from using a process which is the subject-matter of the patent ...;

(c) from offering, putting on the market, using, or importing or stocking for these purposes the product obtained directly by a process which is the subject-matter of the patent.

In some states, acts such as offering the patent can be a patent infringement in the territory even if the patented object is situated outside the territory, for example in the Area. ${ }^{49}$

Despite such rules, patents are not well protected in the Area. States could easily extend their patents legislation to remedy this (which may raise the need for choice of law rules). It is not necessary that the ISA intervenes, and the conditions for the use of its incidental powers are not fulfilled. ${ }^{50}$

\subsection{Mortgages on Property, etc. Used in Seabed Activities}

An activity like deep seabed mining requires a significant amount of capital to invest in ships, rigs, and other equipment. Loan financing is a common way to obtain such capital if the enterprise engaging in the activity can offer the bank a privileged position in its eventual bankruptcy by way of mortgage. In that way, the bank could seize ships, rigs, and other equipment for repayment

48 Convention for the European Patent for the Common Market, annexed to Council Agreement relating to Community Patents, 1989 (89/695/EEC).

49 Stenvik (fn. 45), p. 292-293.

5o See above in section 2.1. 
if necessary. A bank is likely to find an enterprise attractive for loans if its security interest in the equipment is legally recognized and protected by a system of law.

Such systems for recognition and protection of mortgagee banks could either be a register similar to land registries or an alternative pledge. The systems vary with the assets offered as collateral. In either case, the question is whether such systems are established or could be established in the Area.

\subsubsection{Registrable Items}

Recording of mortgages in a registry is well known for ships, and applies equally well to ships used in exploiting the Area. Although such registries are neither uniform nor universal, the systems in different jurisdictions are similar enough to form a single workable system. Ownership and mortgages are recognized based on the ship's registration in a flag state. ${ }^{51}$ Forced sales may be carried out if a vessel is present in the jurisdiction, although such sales may not be recognized by all states. ${ }^{52}$ Some states have ways to order ships flying their flags to proceed to an appropriate jurisdiction for a forced sale. ${ }^{53}$

Some valuable equipment on the vessel may be considered an appurtenance even if it is not required for navigation. ${ }^{54}$ This legal status creates clarity, but may come as a surprise if the owner or mortgagee of the equipment is not the owner or mortgagee of the vessel. In particular, in offshore exploitation, the value of the appurtenances may exceed the value of the vessel.

The same types of rules often apply to floating platforms. Regardless of whether they are considered ships by conventions or customary public international law, such platforms usually have a flag state and they are registered in a particular state, similar to ships. ${ }^{55}$ Again, flag state jurisdiction saves the day in respect of mortgages, and coastal state jurisdiction in respect of arrest and enforcement.

Fixed installations could be subject to a similar system. While registration of mortgages is organized by a state when the platform is located on its

$5^{1}$ See, for example, International Convention on Maritime Liens and Mortgages (fn. 25), art. 1.

$52 \quad$ Ibid. art. 12.

53 See, for example, the Norwegian Enforcement of Claims Act, 1992, Ch. 11 IV and s. 11-3.

54 See to this E Røsæg, Liens and Mortgages on the Ship - Their Relation to the Charterer's Equipment on Board in O Basurko and JMM Osante, New Trends in Maritime Law : Maritime Liens, Arrest of Ships, Mortgages and Forced Sale (2017) p. 339 ff. and B-E Reinertsen Konow, Løsørepant over landegrenser (2006) p. $176 \mathrm{ff}$.

See, for example, Norwegian Maritime Code, 1994, s. 507. 
continental shelf ${ }^{56}$ without any particular legal basis in international law, ${ }^{57}$ the ISA has not organized a similar registry for the Area. As long as this situation is maintained, platforms could be recorded in a registry similar to a ship registry by a willing flag state. It is likely that that the flag and registered encumbrances would be recognized in the same way as ships and floating platforms. For practical reasons, a forced sale must be carried out while the installation remains onsite, but such a sale would be organized and recognized by the state of registry. However, it is less certain that other states would recognize the sale. In any event, the fixed installation may not be worth much if the associated project is doing poorly.

In all these cases (ships, appurtenances, floating platforms, and fixed installations), unsecured creditors could secure their claims through the legal system of the state of registry. The arrangements for fixed installations may not be widely recognized, and alternatives may be necessary. ${ }^{58}$

\subsubsection{Non-Registrable Items}

In addition to registrable units and their appurtenances, it is likely that there is other valuable equipment at a site, such as remotely operated vehicles (ROvs). Can these effectively be offered as collateral for financing of, for example, a mining project?

Usually, pledges are governed by the laws of the state in which the equipment is located (lex rei sitae). ${ }^{59}$ However, in our case, the equipment is not located in a state and thus there are no relevant laws. Therefore, the creditors cannot get the desired certainty that they are secured creditors.

56 See, for example, Norwegian Petroleum Act, 1996, ch. 6 and HLJ Roelvink, Het continentaal plat als IPR-aanknopingspunt, SCJJ Kortmann et al (ed.), Op recht : bundel opstellen, aangeboden aan Prof. Mr. A.V.M. Struycken ter gelegenheid van zijn zilveren ambtsjubileum aan de Katholieke Universiteit Nijmegen (1996).

57 UNCLOS art. 77: "The coastal State exercises over the continental shelf sovereign rights for the purpose of exploring it and exploiting its natural resources." There are examples of express powers in this respect, for example Abkommen zwischen Norwegen und Deutschland über den Transport von Gas durch eine Rohrleitung vom norwegischen Festlandsockel und von anderen Gebieten in Deutschland (1993), art. 3.

58 See below in section 3.3.2.

59 See, for example, C Wendehorst art. $43 \mathrm{mn} .83$ in HJ Sonnenberger et al., Münchener Kommentar zum Bürgerlichen Gesetzbuch : Bd. 11 : Internationales Privatrecht: Internationales Wirtschaftsrecht, Einführungsgesetz zum Bürgerlichen Gesetzbuche (Art. 25-248) (5. Ed. 2010) and A-R Borner, Comment on the Private Law Aspects of the Nord Stream Pipeline, $5^{2}$ German Y.B. Int'l L. 355 (2009) p. 360. 
It has been suggested that the law of the first jurisdiction where the equipment arrives should be the governing law. ${ }^{60}$ However, this will not create foreseeability for the pledgee. A better alternative would be the law of the state of the owner or the law of the last state the equipment was located in before its deployment to the Area. However, these are not widely accepted rules and cannot be counted on to create foreseeability.

Regardless of registration, ownership is likely to be recognized by all courts pursuant to rules that are based on contract and therefore quite similar. An effective pledge on the equipment could therefore be achieved by pledging the shares of the company that owns it, which may be registered in any state. The pledging is then dealt with ashore in a way that creates foreseeability, removed from the legal difficulties of the deep seabed.

Problems may arise if the equipment-owning company goes bankrupt. As mentioned previously, bankruptcy proceedings may occur in a state other than the one in which the equipment-owning company is located. ${ }^{61}$ Usually, such proceedings will take place in the state in which the debtor's center of main interest (COMI) is located, which may not recognize the security interest in the equipment or the shares.

Because of this, equipment-owning companies should have a CомI in their states of incorporation. As some bankruptcy courts may look for a common сомI among a group of companies, it may also be wise to ensure that the COMI of the group is located in the state in which the proceedings take place.

With the necessary precautions regarding the location of the bankruptcy, pledging of non-registrable assets in the Area could effectively be arranged by pledging the shares of the company that owns them.

\subsubsection{The License}

The value of an exploitation license can be used as collateral. Pledging or mortgaging the license does not include the value of the equipment on site.

In the draft regulations, approval of the ISA is necessary to establish such security interests, ${ }^{62}$ and the security interest can be registered in a Seabed Mining Register run by the ISA. ${ }^{63}$

6o Ibid., mn. 106. The Uniform Commercial Code of the United States art. 9-301 points to the location of the debtor or the "local law of the jurisdiction in which the wellhead or minehead is located" in these cases.

$61 \quad$ See above in fn. 41.

62 Draft Regulations on Exploitation of Mineral Resources in the Area (fn. 43), reg. 23. This is in line with UNCLOS, Annex III, art. 20.

63 Ibid., art. 78. 
The Draft Regulations are intended to safeguard the position of the ISA. There are no provisions of recognition or enforcement of the collateral interest in the license. The license is not to be governed by any specific national law, such as the law of the sponsoring state. ${ }^{64}$ The value of a collateral interest in the license in the bankruptcy of the licensee is therefore open to doubt. This point is crucial, as the entire purpose of collateral is to secure the interests of the pledgee or mortgagee in the case of a bankruptcy.

\subsubsection{Conclusion}

In summary, it seems possible to overcome most problems regarding security interests and property seizure in the Area. Intervention of the ISA is therefore not warranted beyond what has been proposed, perhaps with the exception of a register for fixed installations.

\subsection{Labor Law in the Area}

Deep sea mining is likely to employ a number of people offshore. For onshore mining, employment contracts are subject to mandatory legislation in many states (as well as work safety legislation and the right to form labor unions). How could similar legislation be brought about in the Area?

The ISA previously drafted a provision that would make the relevant legislation of the sponsoring state applicable and require use of ships from flag states that had implemented the key international conventions. ${ }^{65}$ Now the approach is to make the contractor responsible for compliance with international and other standards, regardless of the flag of the vessel: ${ }^{6}$

2. The Contractor shall ensure compliance with the applicable international rules and standards established by competent international organizations or general diplomatic conferences concerning ... the treatment of crewmembers, as well as any rules, regulations and procedures and Standards adopted from time to time by the Council relating to these matters.

64 Ibid., art. 18.

65 Developing a Regulatory Framework for Mineral Exploiting in the Area. Report to Members of the Authority and all stakeholders (ISA 2016), Annex VII (to Annex I) Standard Clauses for Exploitation Contract. This is well in line with UNCLOS art. 146, which defines the task of the ISA in respect of protection of human life to supplement existing international law.

Draft Regulations on Exploitation of Mineral Resources in the Area (fn. 43), reg. 32. 
3. In addition, Contractors shall:

(a) Comply with the relevant national laws relating to vessel standards and crew safety of their flag State in the case of vessels, or their sponsoring State or States in the case of Installations; and

(b) Comply with the national laws of its sponsoring State or States in relation to any matters that fall outside of the jurisdiction of the flag State, such as worker rights for non-crew members and human health and safety that pertains to the mining process rather than to ship operation.

At a stroke, this provision will make a set of relevant regulations applicable. A diligent sponsoring state or flag state may even issue special regulations for this activity if necessary. The IMO is now preparing safety regulations for crew carriage, ${ }^{67}$ which is very relevant for offshore mining.

When enacting the draft provisions on safety, labor, and health standards, the ISA has effectively resolved the matter of labor protection legislation. There is no vacuum. However, in case of redundancy of regulation, there are no choice of law provisions giving the legislation of the flag state or the sponsoring state precedence.

\subsection{Extra Contractual Liability for Damages Caused by Activities in the Area}

Offshore mining will most likely cause damage from time to time. The licensee is responsible for such damage: 68

Article 22 Responsibility

The contractor shall have responsibility or liability for any damage arising out of wrongful acts in the conduct of its operations, account being taken of contributory acts or omissions by the Authority.... Liability in every case shall be for the actual amount of damage.

The basis for liability is not exhaustive, ${ }^{69}$ and the licensee may also be held liable under national law, for example where the damage occurs.

67 Imo Document MSc 97/22/Add.1, Annex 11, Resolution Msc.418(97) (2016) Interim Recommendations on the Safe Carriage of More Than 12 Industrial Personnel on Board Vessels Engaged on International Voyages.

68 UNCLOS, Annex III.

69 UNCLOS art. 304 and 235. Also the ISA and the sponsoring states may incur liability, see UNCLOS art. 139 and Kristoffer Svendsen's contribution to this volume. 
The liability will eventually be backed by insurance ${ }^{70}$ and a trust fund. ${ }^{71}$ The liability rules will be detailed to some extent. ${ }^{72}$ However, the regulation is a long way from becoming a full-fledged liability law. ${ }^{73}$ In most states, such a law takes years to develop, and is adapted to local laws and conditions. Yet, this is probably as far as one can get in developing a special torts law for the Area.

\section{Commercial Framework Legislation When There Is No ISA Authority}

The discussions above have assumed ISA authority. However, this assumption is not always correct. On the one hand, a state that is not a party to the UNCLOS (or companies registered in that state) may be involved. These states are not bound to recognize the decisions of the ISA. The most important example is the USA, but (as already mentioned) American companies tend to operate in the Area via subsidiaries registered in a state party to the UNCLOS.

On the other hand, ISA may not be involved because the activity in question falls outside its mandate. The mandate of the ISA is limited to "activities in the Area", see in particular:

Article 153 System of exploration and exploitation

1. Activities in the Area shall be organized, carried out and controlled by the Authority on behalf of mankind as a whole in accordance with this article as well as other relevant provisions of this Part and the relevant Annexes, and the rules, regulations and procedures of the Authority.

Similar limiting references to the "activities in the Area" are found in other parts of article 153 as well as other key provisions setting out the competence of the ISA. ${ }^{74}$

70 Draft Regulations on Exploitation of Mineral Resources in the Area (fn. 43), reg. 38. It is not clear from the wording whether one also has liability insurance in mind.

71 Ibid., reg. $5^{2} \mathrm{ff}$. This was suggested by ITLOS, see Responsibilities and obligations of States with respect to activities in the Area (fn. 31) para 205.

72 Draft Regulations on Exploitation of Mineral Resources in the Area (fn. 43), Annex x Standard clauses for exploitation contract, section 6-8.

73 See, for example, the issues listed in ISA Discussion Paper No. 4 Enforcement and Liability Challenges for Environmental Regulation of Deep Seabed Mining (1996) p. 24.

Articles 140(2), 144, 145, 146, and 147. 
The term "activities in the Area" is much narrower than it first appears due to the definitions. Article 1 of UNCLOS defines the term in this way:

Article 1

1. For the purposes of this Convention:-

(3) "activities in the Area" means all activities of exploration for, and exploitation of, the resources of the Area;

Thus, "activities in the Area" is limited to one specific activity, namely exploration for, and exploitation of, the resources of the Area. The key term "resources" is further narrowed in article 133:

Article 133

For the purposes of this Part:

(a) "resources" means all solid, liquid or gaseous mineral resources in situ in the Area at or beneath the seabed, including polymetallic nodules;

Therefore, the term "activities in the Area" and the mandate of the ISA is limited to all activities of exploration for, and exploitation of, all solid, liquid or gaseous mineral resources in situ in the Area at or beneath the seabed, including polymetallic nodules of the Area. Activities outside the mandate of the ISA include marine scientific research, historical and archeological research, pipelines and cables ${ }^{75}$ catch of sedentary species, thermal energy, $\mathrm{CO}_{2}$ storage, and utilization of genetic resources at the seabed, if any.

UNCLOS article 157 apparently suggests that the ISA has a wider mandate:

Article 157 Nature and fundamental principles of the Authority

1. The Authority is the organization through which States Parties shall, in accordance with this Part, organize and control activities in the Area, particularly with a view to administering the resources of the Area.

The part starting with "particularly" perhaps suggests that the mandate is wider than "the resources in the Area". However, the first part of the sentence confirms that the mandate is limited to "activities in the Area", in line with the other provisions of UNCLOS. The idea is then presumably to state that when

See also UNCLOS art. 87(1)(c) and 112. 
organizing and controlling, particular attention should be given to administering the resources.

On this basis, it is submitted that situations exist, in which the ISA is not recognized or that fall outside the authority of the ISA. How would then framework legislation for commercial activities in the Area be dealt with?

The discussions above conclude that regulation in the Area in many cases must rely on flag state jurisdiction and jurisdiction over companies (or individuals). This was so in relation to patens as well as mortgages and other securities. ${ }^{76}$ This kind of jurisdiction is available also outside the authority of the ISA. The mechanism requires that all involved states take responsibility, exactly as within the authority of the ISA.

Registering security interests in licenses is possible even if the licenses are issued by a state, and not by the ISA. ${ }^{77}$ However, the license is perhaps not much worth when any state can issue a new one with the same right, and the rights under the license might not be recognized by other states.

Labor protection within the authority of the ISA is based on a duty for the licensee to comply with international standards and national legislation of sponsoring states and flag states. ${ }^{78}$ Outside the authority of ISA, there are no sponsoring states, but other involved states may enforce rules based on flag state or personal jurisdiction. Such rules may or may not comply with international standards. If they do not, there is no mechanism to enforce compliance. This makes it possible for entrepreneurs to choose to involve states with lenient enforcement or lenient standards.

Extra contractual liabilities for activities subject to ISA authority is based on special, positive law, ${ }^{79}$ which is not applicable in other cases. However, there is a long-standing practice that states can seize jurisdiction where the damage has occurred and apply their own substantive torts law or their own choice of law rules. ${ }^{80}$ There may be some difficulties enforcing the judgement, and there is no insurance or trust fund to back it.

In sum, the commercial framework legislation is much less well developed outside the scope of the authority of the ISA.

$76 \quad$ See section 3.2 and 3.3 above.

77 See section $3 \cdot 3 \cdot 3$ above.

78 See section 3.4 above.

79 See section 3.5 above.

8o For example PK Mukherdjee, Jurisdictional issues in maritime zones, the high seas and conflict of laws. 24 Journal of International Maritime Law 273 (2018) is apparently based on this assumption. 
Making a new legal order is not easy, even if only for the needs of the Area. The safest route is to use the legal systems of existing states and in particular the sponsoring states and flag states. This route may create choice of law problems, as the legislation of many states may be relevant. If using local law is not possible, then - and only then - the ISA could develop new rules under its inherent jurisdiction, available only when necessary. Developing such a new law is challenging, and it is not immediately obvious that states will recognize and enforce it.

In patents law, there is a problem that the law is national, and that national patents laws as a rule are not extended to the Area. In respect of security interests such as mortgages, only securities in the license is regulated by the ISA. Securities in the involved ships are subject to flag state jurisdiction, while security interests in other units may have to be arranged by pledging the shares in the company that owns them. Labor law in the area is subject to the applicable international conventions and legislation of flag states and sponsoring states by an obligation put on the contractor to make sure these standards are complied with. Liability rules are still fragmentary, but emerging under the auspices of the ISA.

Outside the scope of the authority of the ISA, the commercial framework legislation is much less reliable than within its authority. 